\title{
Rendemen Pengupasan Finir pada Mesin Rotary Lathe Jenis Spindleless dengan Mutu dan Diameter Bahan Baku Log-block yang Berbeda
}

\author{
Rendement of Peeled Veneer on Spindleless Rotary Lathe with Different Quality and \\ Diameter of Log-block Raw Material
}

\author{
Syafii ${ }^{1 *}$ dan Firna Novari ${ }^{2}$
}

${ }^{1}$ Program Studi Rekayasa Kayu, Politeknik Pertanian Negeri Samarinda, Indonesia

${ }^{2}$ Program Studi Pengolahan Hasil Hutan, Politeknik Pertanian Negeri Samarinda, Indonesia

${ }^{*}$ Corresponding Author: aliefsyafii.10@gmail.com

\begin{abstract}
Abstrak
Rotary lathe dengan spindel besar masih banyak digunakan di pabrik finir dan kayulapis di Indonesia, dan selama ini rata-rata separuh kayu bulat bahan baku menjadi limbah, dan 25 persennya disumbang di mesin rotary lathe. Sementara itu di sisi lain, kebutuhan dunia terhadap produk kayulapis tidak akan pernah hilang bahkan akan terus meningkat. Pasalnya, kayulapis adalah satu produk bahan bangunan yang paling ramah lingkungan dan berasal dari sumber daya alam yang dapat diperbarui. Pertumbuhan kembali industri kayulapis seperti masa jayanya dulu, berkonsekuensi meningkat pula kebutuhan log bahan bakunya, dan dengan sendirinya potensi kehilangan log sebagai limbah akan meningkat pula. Sehingga harus ada perubahan mendasar pada industri ini, di antaranya adalah perubahan mesin produksi dari rotary spindle besar ke rotary tanpa spindle (spindleless). Penelitian ini bertujuan untuk mengetahui rendemen dan jumlah finir hasil kupas mesin rotary lathe spindleless serta produk lain yang menyertai berupa empulur (logcore) dan potongan tepi (waste spur-knife). Analisis hasil penelitian menunjukkan bahwa, secara umum rotary lathe spindleless memberikan rendemen lebih $60 \%$, berupa finir gulung (continuous/endless veneer) dan finir inti (poly piece core) pada semua kelas mutu dan kelas diameter, dan selebihnya adalah limbah yang berupa finir round-up dan empulur hingga 15\% dengan diameter rata-rata $23 \mathrm{~cm}$. Jika pengupasan dilanjutkan hingga diameter $7 \mathrm{~cm}$, akan menambah rendemen finir lebih dari $10 \%$.
\end{abstract}

KATA KUNCI: Spindleless rotary lathe, Finir, Rendemen

\begin{abstract}
Rotary lathe with large spindles are widely used in veneer and plywood factories in Indonesia. On average, half of the raw material logs become waste and $25 \%$ is contributed by the rotary lathe. Meanwhile, on the other hand, the world's need for plywood products will never disappear and even continue to increase. This is because plywood is one of the most environmentally friendly building material products and comes from renewable natural resources. With the regrowth of the plywood industry as in its former heyday, the consequence is that the demand for log raw materials will also increase, and the potential for loss of logs as waste will also increase. In this regard, there must be fundamental changes in this industry, including the change in production machines from large rotary spindles to spindle-less. The purpose of this research is to analyze its contribution to increasing the yield or peeled veneer volume. Besides, to find out the volume of the by-products, log-core, and waste spur-knife. The analysis of this study shows that, in general, spindleless rotary lathe provide a yield of more than $60 \%$ of the log raw material, in the form of a continuous veneer and a poly piece core, in all quality and diameter classes, and the rest is waste in the form of round-up veneer and log-core up to $15 \%$ with an average diameter of $23 \mathrm{~cm}$. If peeling were continued to a diameter of $7 \mathrm{~cm}$, this would increase the finished yield by more than $10 \%$.
\end{abstract}

KEY WORDS: Spindleless rotary lathe, veneer, rendement 


\section{PENDAHULUAN}

Kebutuhan dunia terhadap produk finir dan atau kayulapis tidak akan pernah hilang bahkan akan terus meningkat. Pasalnya, kayulapis adalah satu produk bahan bangunan yang paling ramah lingkungan dan berasal dari sumber daya alam yang dapat diperbarui. Karenanya industri kayulapis harus didorong untuk melakukan perubahan positif seperti, perubahan penggunaan bahan baku dari kayu hutan alam ke kayu tanaman, terutama kayu sengon, perubahan dari industri skala besar ke industri skala kecil menengah, perubahan mesin produksi dari rotary lathe dengan spindle besar ke rotary tanpa spindle (spindleless), dan yang disebut terakhir ini yang paling penting karena menjanjikan rendemen finir hasil kupasnya yang lebih tinggi dan lebih baik mutunya. Penelitian ini bertujuan untuk memberikan gambaran tentang rendemen yang dihasilkan oleh mesin kupas spindleless tersebut, terutama rendemen dalam bentuk continuous veneer dan poly piece veneer core. Menurut Kollmann, et al (2013), kayu yang lazim digunakan sebagai bahan baku finir atau kayulapis di Asia terutama adalah dari famili Dipterocarpaceae. Kendati kayu ini tedapat di hutan campuran, jenis dipterocarpa ini jumlahnya lebih dari separuh potensi tegakan yang ada di dalamnya dan hanya dibedakan oleh kekuatan, kelurusan serta bebas-mata kayu pada batangnya. Meranti merah, Lauan Putih dan Mersawa, untuk menyebut beberapa contoh. Jenis lainnya adalah Jelutung dan Ramin. Persyaratan yang harus dipenuhi oleh log untuk pembuatan finir adalah serat harus lurus. Penyimpangan dari ketentuan ini diperkenankan sebatas masih dapat dipandang ekonomis dan memenuhi syarat mutu. Karena bagaimanapun log yang digunakan sebagai bahan baku finir berharga mahal. Persyaratan lain, log harus bulat atau silindris. Dumanauw (2003) mensyaratkan bahwa untuk membuat finir atau kayulapis log harus berdiameter besar, bulat, bebas cacat atau beratnya sedang. Meranti merah, Meranti putih, Nyatoh, Ramin, Agathis, Benuang, adalah beberapa contohnya. Haygeen dan Bowyer (2007) menegaskan bahwa mutu kayu bulat untuk finir ditentukan oleh tidak adanya mata kayu atau cacat permukaan, kelurusan dan kesilindrisan, dan oleh terbebasnya bagian ujungnya dari cacat. Busuk bontos juga merupakan masalah serius log untuk finir. Kelas mutu biasanya ditetapkan atas dasar kelurusan, bebas dari busuk bontos atau lunak di bagian tengah, dan bebas dari matakayu atau cacat-cacat lainnya. Selanjutnya dikatakan, mutu kayu bulat yang masuk ke pabrik penting karena dua hal: megendalikan mutu dan hasil finir yang dihasilkan dan mengurangi jumlah kayu bulat yang terbukti cacat setelah dipasang pada mesin kupas. Kayu bulat atau sawnlog yang cacat dapat mengurangi kecepatan produksi mesin kupas (Haygeen dan Bowyer, 2007). Almeida et al (2013), Frûehwald (1986) menerangkan secara lebih rinci persyaratan-persyaratan yang harus dipenuhi oleh log yang akan dikonversikan menjadi lembaran finir, yaitu: tersedia dalam jumlah yang banyak, kerapatan antara $0,35-0,8 \mathrm{~g} / \mathrm{cm}^{3}$, diameter $>40 \mathrm{~cm}$, batang lurus dan silindris, serat lurus, bebas cacat (seperti mata kayu, pinhole, pecah ujung atau permukaan), memeiliki sifat mekanik yang tinggi, berstrktur dekoratif, warna ringan serta harga murah.

Menurut Kollmann et al (2013), kebanyakan finir dihasilkan dengan cara pengupasan rotary (rotary-peeling), yang merupakan basis industri kayulapis modern. Rotary-peeling tujuannya adalah untuk menghasilkan endless veneer (finir panjang yang berkesinambungan). Kendati tidak sempurna betul, finir yang dihasilkan dngan cara ini halus pada kedua permukaannya. Dijelaskan dalam Britannica (2019) bahwa lebih dari 90 persen finir merupakan hasil kupasan, tetapi finir yang dihasilkan dari kayu figuratif untuk furnitur dan untuk kegunaan dekoratif lainnya diperoleh dengan menyayat, sedangkan finir gergajian jarang diproduksi karena banyak menghasilkan sampah.

\section{METODE PENELITIAN}

Penelitian dilaksanakan di pabrik pembuatan kayulapis (plymill), di desa Loa Kulu, Kabupaten Kutai Kartanegara, Kalimantan Timur, yaitu PT Rimba Raya Lestari (PT RRL). Dalam hal ini bahan yang menjadi obyek penelitian hanya log dari jenis Meranti Merah. 


\section{Prosedur persiapan sebelum pengupasan finir.}

Setelah kayu gelondongan (log) yang berukuran panjang $(10-17 \mathrm{~m})$ dipotong dengan ukuran tertentu: 3', 4', 6' dan 8', logblock tersebut diukur kembali pada arah panjang dan diameternya untuk keperluan menghitung volume in-put bahan baku. Selanjutnya blok dibawa ke mesin log debarker untuk membuang seluruh kulit dan benda lainnya yang melekat pada permukaannya atau benda asing yang melekat pada blok tersebut. Dari log debarker masih dengan roll conveyor yang sama blok bergerak ke arah log cleaning device untuk dilakukan penyemprotan air bertekanan tinggi guna membersihkan sisasisa kotoran yang masih melekat pada blok. Dalam hal ini tidak dilakukan perlakuan pendahuluan yang berupa pengukusan (logblock steaming) dan perebusan (boiling).

\section{Pengupasan blok (log peeling).}

Blok ditempatkan di dek chain conveyor untuk menunggu giliran penentuan titik kupas (log-block centering) selanjutnya blok dibawa menuju mesin kupas (rotary lathe). Hoist yang dilengkapi penjepit menjalankan tugas ini sampai blok dicengkeram oleh dua cakram (spindle). Pada saat proses pengupasan berjalan, pelan-pelan cakram ditarik sehingga blok yang tetap berputar berlawanan dengan pisau pengerat, hanya dijepit oleh knife-holder dan roda-roda nosebar. Hasilnya berupa finir panjang (continuous veneer) digulung lalu di tempatkan sementara di dek-dek penggulung dan pengurai finir (reelingunreeling veneer), pada saat yang bersamaan di awal dan di akhir pengupasan dihasilkan juga odd-veneer (poly piece core), finir potongan tepi (spur-knife waste). Proses pengupasan ini berakhir dengan menyisakan empulur (log-core).

\section{Penanganan finir dan hasil kupas lainnya.}

Seluruh finir hasil kupas diukur tebalnya, baik continuous finir untuk face/back, finir inti (poly piece core) dan finir potongan tepi (spur-knife waste). Khusus untuk gulungan finir pada dek-dek reelingunreeling veneer diukur jari-jarinya $(r, \mathrm{~cm})$ untuk keperluan menghitung diameternya $\left(B_{v}, \mathrm{~m}\right)$, demikian juga panjangnya $(/ \mathrm{cm})$.
Setelah diameter bobbin penggulung diketahui $\left(B_{b}, m\right)$ kemudian dilakukan penghitungan volume finir. Volume hasil penghitungan ditandai sebagai $\left(V \mathrm{~cm}^{3}\right)$. Empulur (log core) diukur panjang (I) dan diameternya (d) juga untuk keperluan penghitungan volumenya, selanjutnya diarahkan ke tempat penumpukan melalui saluran di bawah mesin rotary lathe yang dilengkapi dengan v-belt conveyor.

\section{Pengukuran dan pengujian.}

Pengukuran diameter, volume log-block dan volume finir pada gulungan dihitung menurut rumus-rumus di bawah ini (Syafii, 2019). Diameter log-block dan empulur dengan rumus (1):

$$
D=\frac{1 / 2\left[\left(d_{1}+d_{2}\right)+\left(d_{3}+d_{4}\right)\right]}{2}(\mathrm{~cm})
$$

Keterangan:

$D=$ diameter log-block atau empulur (dalam $\mathrm{cm}$ ) $d_{1}, d_{2}, d_{3}$ dan $d_{4}=$ diameter hasil empat kali pengukuran $(\mathrm{cm})$

Volume log-block dan empulur dihitung dengan rumus (2):

$$
V=\left(\begin{array}{ll}
1 / 4 \pi & D^{2}
\end{array}\right) \times I\left(\mathrm{~m}^{3}\right)
$$

Keterangan:

$V=$ volume $\left(\right.$ dalam $\left.\mathrm{m}^{3}\right)$

$I=$ panjang log-block atau empulur $(\mathrm{m})$

$\pi \quad=3,14$

Volume finir. Volume bruto finir dalam gulungan bobbin pada mesin reelingunreeling dihitung menurut rumus (3):

$V=1 / 4 \pi\left(B_{\mathrm{v}}{ }^{2}-B_{\mathrm{b}}{ }^{2}\right) \times I\left(\mathrm{~m}^{3}\right)$

Keterangan:

$B v=$ diameter gulungan finir $(\mathrm{m})$

$B b=$ diameter bobbin $(m)$.

Rendemen finir, baik continuous veneer maupun poly piece core veneer (PPC) dihitung dengan rumus (4):

Rendemen $=$

$\underline{\text { Volume finir hasil kupasan setiap log-block }} \times 100 \%$

\section{Perlakuan dan rancangan percobaan.}

Untuk melihat pengaruh perlakuan dan interaksi antar perlakuan terhadap keluaran (out put) hasil kupas di mesin rotary lathe, 
data dan hasil perhitungan kemudian ditabulasikan dan dianalisis berdasarkan rancangan percobaan fatorial dengan 2 perlakuan dan masing-masing dengan 3 taraf $\times 5$ taraf, terdiri atas: 1) Faktor A (mutu log-block) yang terdiri dari 3 level yaitu kelas $A\left(a_{1}\right)$, kelas $B\left(a_{2}\right)$ dan kelas $C$ $\left.\left(a_{3}\right) ; 2\right)$ dan Faktor $B$ (diameter) yang terdiri atas 5 level yaitu kelas diameter $50-54 \mathrm{~cm}$ $\left(b_{1}\right), 55-59 \mathrm{~cm}\left(b_{2}\right), 60-64 \mathrm{~cm}\left(b_{3}\right), 65-$ $69 \mathrm{~cm}\left(\mathrm{~b}_{4}\right)$, dan $70-44 \mathrm{~cm}\left(\mathrm{~b}_{5}\right)$.

\section{HASIL DAN PEMBAHASAN}

Hasil pengamatan meliputi ukuran diameter, panjang dan volume log-block bahan baku yang diumpankan pada kedua tipe mesin rotary lathe.

Tabel 1. Rata-rata Hasil Pengukuran Dimensi Log-block yang Diumpankan Pada Mesin Rotary Lathe Spindleless

\begin{tabular}{|c|c|c|c|c|}
\hline \multicolumn{2}{|c|}{$\begin{array}{l}\text { Faktor-faktor } \\
\text { Mutu }\end{array}$} & \multirow{2}{*}{$\begin{array}{c}\text { Diameter } \\
(\mathrm{cm})\end{array}$} & \multirow{2}{*}{$\begin{array}{c}\text { Panjang } \\
\text { (cm) }\end{array}$} & \multirow{2}{*}{$\begin{array}{c}\begin{array}{c}\text { Volume } \\
\left(\mathrm{m}^{3}\right)\end{array} \\
0,4254\end{array}$} \\
\hline & Minimum & & & \\
\hline A & Maksimum & 82,00 & 261,80 & 13,750 \\
\hline & Rata-rata & 63,13 & 260,31 & 0,8300 \\
\hline \multirow{3}{*}{ B } & Minimum & 52,00 & 257,70 & 0,5470 \\
\hline & Maksimum & 74,70 & 261,30 & 11,389 \\
\hline & Rata-rata & 62,14 & 259,75 & 0,8000 \\
\hline \multirow{3}{*}{ C } & Minimum & 51,00 & 259,00 & 0,4254 \\
\hline & Maksimum & 72,00 & 260,00 & 13,750 \\
\hline & Rata-rata & 61,00 & 259,51 & 0,8300 \\
\hline
\end{tabular}

Rata-rata diameter log-block yang diumpankan pada rotary lathe spindleless adalah $63,13 \mathrm{~cm}$ (pada kelas mutu A), 62,14 $\mathrm{cm}$ (kelas mutu B) dan $61,00 \mathrm{~cm}$ (kelas mutu C). Dengan rata-rata volume hampir sama pada ketiganya yaitu $0,80 \mathrm{~m}^{3}$. Pada setiap pengupasan log-block menjadi lembaran finir dipastikan diikuti oleh 3 hasil ikutan lainnya berupa limbah, keciali log-core. Sebagian besar hasil kupasan adalah finir gulung (continuous/endless veneer) sebesar masing 60,09 \% (kelas mutu log-block A), $57,57 \%$ (mutu B) dan 54,95\% (mutu C). Selanjutnya adalah poly piece core (odd veneer) berturut-turut $25,66 \%$ (mutu A), $19.80 \%$ (mutu B) dan 18,20\% (mutu C). Volume log-core pada kelas mutu log-block A, B dan C berturut-turut adalah $12,13 \%$; $15,06 \%$ dan $11,84 \%$. Potongan tepi oleh pisau kerat spur-knife dipastikan menjadi limbah masing-masing besarnya adalah $0,95 \%$ (kelas mutu log-block A), 0,92\% (mutu B) dan 11,84\% (mutu C). Muladi dalam Schulte dan Schone (1996) menyebutkan hasil pengupasan finir di mesin rotary lathe adalah sebanyak $72,84 \%$ dari volume kayu gelondongannya, sisanya $27,16 \%$ adalah sampah. Hasil finir untuk face dan back (continuous veneer) bervariasi $51,88 \%$ (pada merenti kuning) sampai $74,55 \%$ (pada meranti merah). Syafii (2001) melaporkan bahwa 58\% hasil kupasan berupa endless veneer (finir utuh), $27 \%$ odd veneer (finir tak utuh untuk core), $10 \%$ empulur dan limbah potongan tepi (spur-knife) sekitar $5 \%$.

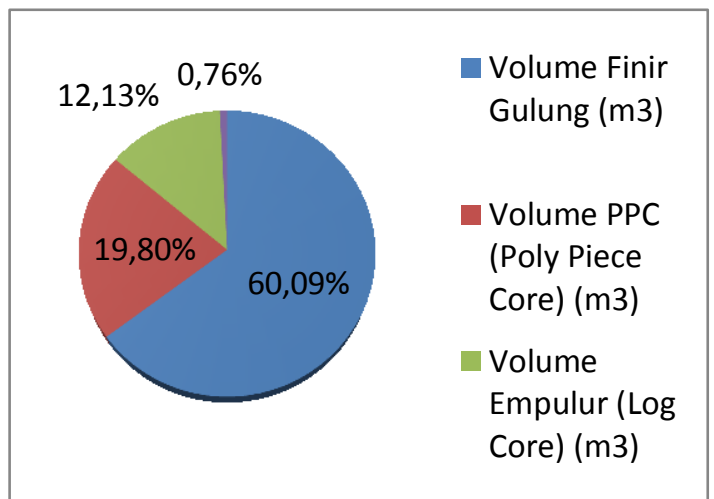

Gambar 1. Grafik Hasil Pengupasan Log-block Mutu A Jenis Meranti Merah dengan Berbagai Kelas Diameter pada Mesin Rotary Lathe Spindleless

Rendemen seringkali dihitung sebagai rasio perolehan hasil kupas berupa finir dengan bahan bakunya. Inilah yang disebut sebagai rendemen finir segar (green veneer recovery), yang memberikan gambaran rendmen maksimum, yaitu seluruh finir yang dapat dimanfaatkan (McGavin, et al., 2014), yang terdiri dari finir gulung dan PPC. Rotary lathe spindleless memiliki potensi besar untuk menggantikan rotary lathe model lama yang umumnya mempunyai spindle atau cakram dengan ukuran diameter besar, sehingga tidak dapat memberikan rendemen maksimum. Mengganti rotary tipe ini dengan tipe spindleless merupakan langkah revolusioner untuk mengembalikan kejayaan industri dan produksi finir dan kayulapis seperti dua dekade belakang. Kayulapis adalah produk primadona dari wood-besed material, yaitu produk panel yang berbahan baku hasil hutan berupa kayu. Gambaran 
rendemen hasil kupas mesin rotary lathe spindleless di atas cukup menggembirakan, walaupun terkadang masih kalah bila dibandingkan rotary lathe conventional ketika yang dikupas adalah log-block berdiameter besar (di atas $80 \mathrm{~cm}$ ).

Penelitian McGavin, et al (2014) menghasilkan bahwa rendemen finir segar dari bebera jenis kayu Eucalyptus berumur antara 10-16 tahun yang dikupas pada mesin rotary spindleless berkisar antara 68$77 \%$. Bahkan rendemen finir blok mutu $\mathrm{A}$ ini lebih tinggi dari hasil penelitian Khoo, et. al. (2018), yang memaparkan hasil penelitiannya bahwa, rendemen finir dari rubber wood yang dikupas dengan mesin spindleless pada kisaran $62-66 \%$. Alfian, dkk (2019) menyatakan bahwa rendemen finir dari kayu kelompok jenis komersial satu (kayu bulat berdiameter besar) rata-rata $71,0 \%$. Nilai rendemen ini jauh di bawah dari hasil penelitian ini yang berkisar antara 78,42-85,90\%. Demikian juga penelitian Balfas dan Malik (2020) memaparkan tentang pembuatan finir dengan rotary lathe spindleless 5 feet dari batang sawit menghasilkan rendemen dengan kisaran $78,82-79,96 \%$.

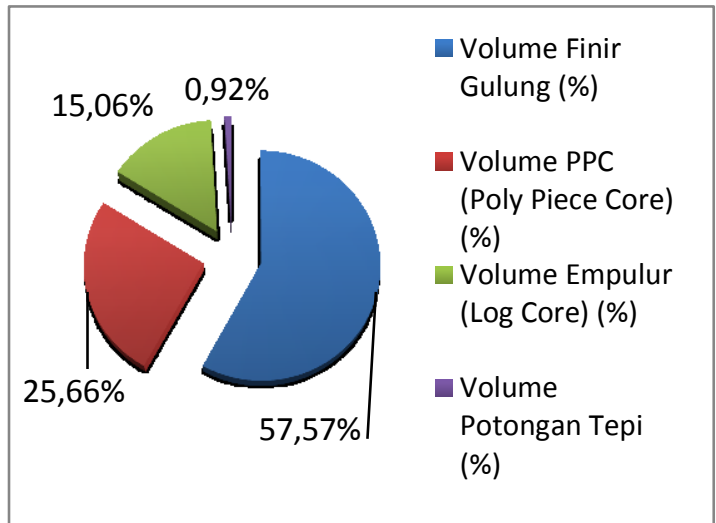

Gambar 2. Grafik Hasil Pengupasan Log-block Mutu B Jenis Meranti Merah dengan Berbagai Kelas Diameter pada Mesin Rotary Lathe Spindleless

Finir gulung (continuous veneer). Gambar 1 menunjukkan bahwa hasil kupas blok mutu A pada mesin rotary didominasi oleh finir gulung (continuous veneer) sebanyak $60 \%$ dan hampir 20\%-nya merupakan finir inti. Pengupasan masih menyisakan empulur dengan volume cukup besar sekitar $12 \%$ dan limbah keratan pisau tepi $0,76 \%$. Keadaan sedikit berbeda ditunjukkan oleh hasil kupas blok mutu B. Hasilnya adalah finir gulung $57,57 \%$ dan finir inti $25,66 \%$. Volume empulurnya lebih tinggi lagi $15 \%$ dan limbah potongan tepinya hampir $1 \%$ (Gambar 2).

Hanya sekitar $86 \%$ keadaan output dari mesin rotary yang dapat dihitung pada pengupasan blok mutu C. Sisanya $14 \%$ benar-benar menjadi limbah berupa roundup pada saat pembulatan di kupasan pertama, finir patah dan tidak teratur bentuknya. Finir gulung hasil kupas mencapai $55 \%$ dengan finir initi 18\%. Empulur dan potongan tepi berturut-turut $11,85 \%$ dan $0,93 \%$.

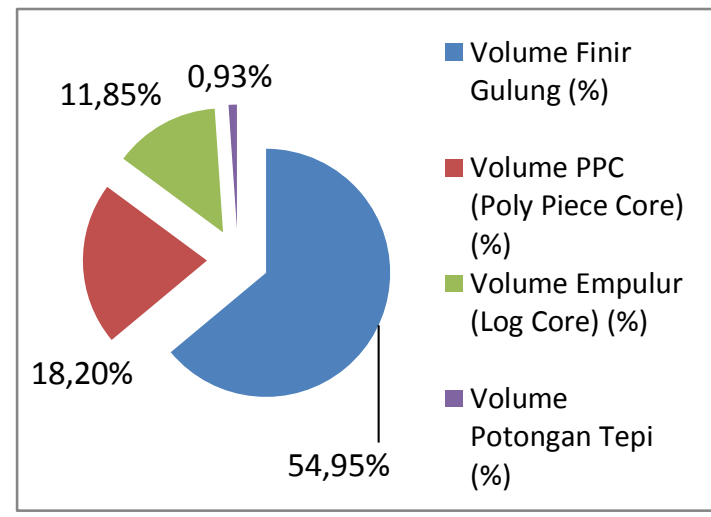

Gambar 3. Grafik Hasil Pengupasan Log-block Mutu C Jenis Meranti Merah dengan Berbagai Kelas Diameter pada Mesin Rotary Lathe Spindleless

Haygeen dan Bowyer (2007) mengidentifikasikan bahwa, dari suatu hasil pengupasan sawn log, diperoleh data: finir utuh hasil kupasan sejumlah $43 \%$ ditambah $1 \%$ finir mutu rendah. Kehilangan akibat pembulatan (rounding) 6\% dan penyusutan finir $3 \%$, sobekan $2 \%$. Kerugian pemotongan ujung (log end) dan tepi $26 \%$ serta ampulur $19 \%$. Menurut Baldwin (1981) volume finir segar (green veneer) berkisar dari 45,89\% sampai 55,05\%. McGavin (2016) memaparkan rendemen berupa green veneer yang hanya $74-77 \%$ ketika mengupas blok dari jenis kayu Eucalyptus globulus yang berumur 13-16 tahun dengan diameter rata-rata mendekati $50 \mathrm{~cm}$. 
Tabel 2. Analisis Ragam (ANOVA) Data Volume Finir Gulung (Continuous Veneer) pada Rancangan Percobaan Faktorial $3 \times 5$

\begin{tabular}{|l|c|c|c|c|c|c|}
\hline \multirow{2}{*}{$\begin{array}{c}\text { Sumber } \\
\text { Keragaman }\end{array}$} & $\mathrm{db}$ & \multirow{2}{*}{$\mathrm{JK}$} & \multirow{2}{*}{$\mathrm{KT}$} & $\mathrm{F}_{\text {hitung }}$ & \multicolumn{2}{|c|}{$\mathrm{F}_{\text {tabel }}$} \\
\cline { 6 - 8 } & & & & & $5 \%$ & $1 \%$ \\
\hline Ulangan & 3 & & & & & \\
\hline Perlakuan & 14 & 0.596 & 0.043 & $0.730^{\text {ns }}$ & 2.06 & 2.8 \\
\hline $\mathrm{A}=$ Mutu & 2 & 0.323 & 0.161 & $2.767^{\mathrm{ns}}$ & 3.34 & 5.45 \\
\hline $\begin{array}{l}\mathrm{B}=\text { Kelas } \\
\text { Diameter }\end{array}$ & 4 & 0.501 & 0.125 & $2.146^{\mathrm{ns}}$ & 2.71 & 4.07 \\
\hline $\mathrm{AB}$ & 8 & -0.227 & -0.028 & $-0.487^{\mathrm{ns}}$ & 2.29 & 3.23 \\
\hline Galat & 28 & 1.63 & 0.058 & & & \\
\hline Total & 89 & 2.252 & & & & \\
\hline
\end{tabular}

Keterangan:

ns $=$ tidak berbeda nyata pada $\alpha=0,05$

$* *$ = berbeda sangat nyata pada $\alpha=0,01$

Apabila nila nilai $\mathrm{F}_{\text {-hitung }}>\mathrm{F}$-tabel, maka perlakuan memberikan pengaruh signifikan ${ }^{* *}$ )

Apabila nilai $\mathrm{F}_{\text {-hitung }}<\mathrm{F}_{\text {-tabel}}$, maka perlakuan tidak memberikan pengaruh signifikan (ns)

Tabel ANOVA di bawah ini (Tabel 3), disusun berdasarkan Gomez \& Gomez (1995), Gaspers (1994) dan Steel dan Torrie (1993), menunjukkan bahwa perlakuan-perlakuan, baik kelas mutu maupun diameter blok ternyata tidak memberikan pengaruh pada volume finir gulung yang dihasilkan, baik pada taraf uji $\alpha=0,01$ maupun $\alpha=0,05$. Nilai $F_{-t a b e l}$ lebih besar dibanding nilai $\mathrm{F}$-hitung. Hasil analisis sidik ragam ini mengindikasikan bahwa kelas mutu dan diameter blok tidak memberikan pengaruh signifikan terhadap besarnya rendemen finir gulung. Ini menujunjukkan bahwa ada faktor lain diluar kedua perlakuan tersebut yang memberikan pengaruh pada volume finir gulung yang dihasilkan, boleh jadi yang cukup berpengaruh adalah kemampuan teknis operator mesin rotary lathe ketika sedang mengupas, atau mungkin juga ketebalan finir yang dikupas. Demikian juga dengan interaksi perlakuan-perlakuan, tidak memberikan pengaruh terhadap volume finir gulung yang dihasilkan. Bahkan nilai $\mathrm{F}_{\text {-hitung }}$ jauh lebih kecil dibanding $\mathrm{F}_{\text {-tabel }}$ pada pada taraf $\alpha=0,05$

Rotary lathe tipe spindleless ini sebenarnya mempunyai kemampuan untuk menyisakan empulur diameter minimal hingga $7 \mathrm{~cm}$ saja. Hanya saja pada penelitian ini, proses pengupasan dihentikan pada saat empulurnya mendekati diameter
$25 \mathrm{~cm}$ atau $20 \mathrm{~cm}$ dengan alasan tertentu. Dalam perhitungan peneliti, jika pengupasan diteruskan hingga empulur mencapai diameter minimal sebagaimana telah disebutkan maka akan memberikan tambahan rendemen finir antara 5-10\%. Bahkan Philips, dkk. (1980) menyatakan bahwa, apabila sawn log dengan diameter 8 inci $(16,25 \mathrm{~cm})$ kemudian dikupas hingga menyisakan empulur dengan diameter 4 inci $(10 \mathrm{~cm})$ akan memberikan rendemen sangat signifikan, yaitu sekitar $21 \%$.

Tabel 3. Analisis Ragam (ANOVA) Data Volume Finir inti (Poly Piece Core) pada Rancangan Percobaan Faktorial $3 \times 5$

\begin{tabular}{|l|c|c|c|c|c|c|}
\hline \multirow{2}{*}{$\begin{array}{c}\text { Sumber } \\
\text { Keragaman }\end{array}$} & $\mathrm{db}$ & $\mathrm{JK}$ & $\mathrm{KT}$ & $\mathrm{F}_{\text {hitung }}$ & \multicolumn{2}{|c|}{$\mathrm{F}_{\text {tabel }}$} \\
\cline { 6 - 8 } & & & & & $5 \%$ & $1 \%$ \\
\hline Ulangan & 3 & & & & & \\
\hline Perlakuan & 14 & 0.058 & 0.004 & $0.538^{\text {ns }}$ & 2.06 & 2.8 \\
\hline $\mathrm{A}=$ Mutu & 2 & 0.097 & 0.048 & $6.249^{* *}$ & 3.34 & 5.45 \\
\hline $\begin{array}{l}\mathrm{B}=\text { Kelas } \\
\text { Diameter }\end{array}$ & 4 & 0.044 & 0.011 & $1.419^{\text {ns }}$ & 2.71 & 4.07 \\
\hline $\mathrm{AB}$ & 8 & -0.083 & -0.010 & $-1.331^{\text {ns }}$ & 2.29 & 3.23 \\
\hline Galat & 28 & 0.217 & 0.008 & & & \\
\hline Total & 89 & 0.277 & & & & \\
\hline
\end{tabular}

Keterangan:

ns $=$ tidak berbeda nyata pada $\alpha=0,05$

$* *$ = berbeda sangat nyata pada $\alpha=0,01$

Finir inti (poly piece core). Keadaan berbeda diperlihatkan oleh hasil analisis keragaman terhadap data finir inti, poly piece core. Nilai $\mathrm{F}_{\text {-hitung }}$ perlakuan dengan kelas mutu blok menunjukkan nilai yang sangat besar (Tabel 3), melampaui nilai nilai $\mathrm{F}_{\text {-tabel, }}$, pada taraf $\alpha=0,05$ dan $\alpha=0,01$, sehingga dapat dikatakan mutu blok berpengaruh sangat nyata terhadap volume finir inti hasil kupasnya. Hanya tidak demikian dengan kelas diameter yang ternyata tidak memberikan pengaruh signifikan terhadap rendemen poly piece veneer core.

Umumnya bentuk blok bahan baku yang diumpankan ke mesin kupas sudah relatif silindris karena memang sejak awal sudah dipilah sedemikian rupa, kecuali pada kasus tertentu seperti ketika sedang terjadi kelangkaan log bahan baku. Karena bagaimanapun log-block yang tidak silindris menjadi penyumbang cukup besar perolehan poly piece core saat pengupasan. 


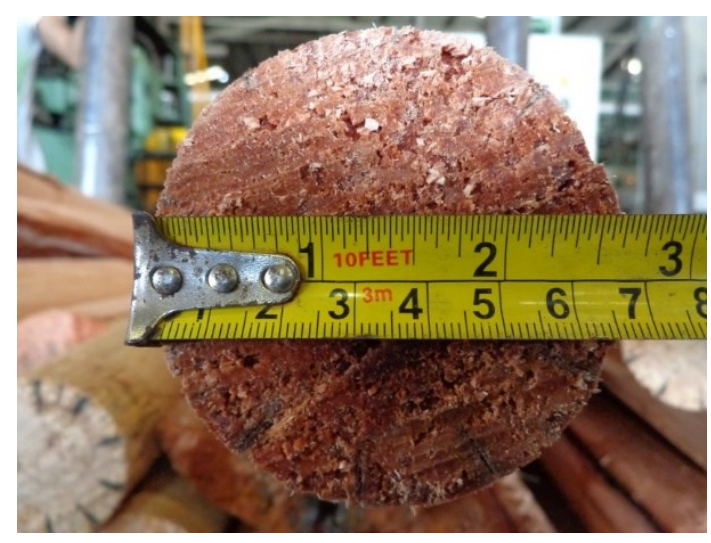

Gambar 4. Empulur akan mecapai diameter minimal jika memaksimalkan mesin rotary lathe tipe spindleless (Foto diambil Peneliti di PT Rimba Raya Lestari, Kutai Kartanegara, Kaltim).

Tabel 3 juga menunjukkan bahwa interaksi perlakuan juga dalam hal ini tidak memberikan pengaruh nyata terhadap volume hasil kupas, baik pada taraf $\alpha=0,05$ maupun $\alpha=0,01$. Artinya perlakuan kelas mutu dan kelas diameter keduanya tidak berinteraksi, sehingga tidak memberikan pengaruh terhadap banyaknya volume finir core yang dihasilkan.

Tabel 4. Analisis Ragam (ANOVA) Data Volume Empulur (Log-core) pada Rancangan Percobaan Faktorial $3 \times 5$

\begin{tabular}{|l|c|c|c|c|c|c|}
\hline \multirow{2}{*}{$\begin{array}{c}\text { Sumber } \\
\text { Keragaman }\end{array}$} & $\mathrm{db}$ & \multirow{2}{*}{$\mathrm{JK}$} & $\mathrm{KT}$ & $\mathrm{F}_{\text {hitung }}$ & \multicolumn{2}{|c|}{$\mathrm{F}_{\text {tabel }}$} \\
\cline { 6 - 8 } & & & & & $5 \%$ & $1 \%$ \\
\hline Ulangan & 3 & & & & & \\
\hline Perlakuan & 14 & -0.030 & -0.002 & $0.588^{\text {ns }}$ & 2.06 & 2.8 \\
\hline $\mathrm{A}=$ Mutu & 2 & 0.018 & 0.009 & $2.426^{\text {ns }}$ & 3.34 & 5.45 \\
\hline $\begin{array}{l}\mathrm{B}=\text { Kelas } \\
\text { Diameter }\end{array}$ & 4 & 0.016 & 0.004 & $1.105^{\text {ns }}$ & 2.71 & 4.07 \\
\hline $\mathrm{AB}$ & 8 & -0.065 & -0.008 & $2.188^{\text {ns }}$ & 2.29 & 3.23 \\
\hline Galat & 28 & 0.104 & 0.004 & & & \\
\hline Total & 89 & 0.077 & & & & \\
\hline
\end{tabular}

Keterangan:

$\mathrm{ns}=$ tidak berbeda nyata pada $\alpha=0,05$

$* *$ = berbeda sangat nyata pada $\alpha=0,01$

Empulur (log-core). Table ANOVA di atas sebenarnya menunjukkan bahwa, nilai F-hitung faktor mutu blok cukup mendekati nilai $\mathrm{F}_{\text {-tabel }}$ pada taraf $=0,05$ sehingga dapat dikatatan hampir memberikan pengaruh signifikan terhadap besarnya volume empulur (Tabel 4). Secara kasat mata memang menunjukkan hal itu, ketika empulur dilepaskan dari penjepit pemutarnya di mesin kupas, diameternya menunjukkan atau berada pada kisaran 20 $\mathrm{cm}$. Sementara menurut Philips, dkk (1980), diameter empulur berpengaruh langsung terhadap jumlah finir yang dihasilkan. Menurutnya, pada sawn-log 18 inci $( \pm 50 \mathrm{~cm})$ meningkatnya finir yang dihasilkan adalah dengan mengurangi diamater ampulur dari 5 ke 4 inci (dari 12,5 $\mathrm{cm}$ ke $10 \mathrm{~cm}$ ), tetapi peningkatan itu tidak signifikan (hanya sekitar 3\%). Tetapi apabila sawn-log 8 inci $(16,25 \mathrm{~cm})$ yang dikupas perbedaannya menjadi sangat signifikan (sekitar 21\%).

Secara teori besar kecilnya volume empulur, yang ditandai oleh besar kecilnya diameter, akan dipengaruhi oleh mutu logblock bahan bakunya, terutama jika log-nya sehat pada bontos dan cukup silindris dan bebas dari retak apalagi pecah. Dengan catatan, operator mesin tidak menghentikan proses pengupasan untuk tujuan tertentu.

Finir potongan tepi (spur-knife waste). Faktor mutu blok ternyata memberikan pengaruh signifikan terhadap perolehan finir potongan tepi, ditandai dengan nilai $\mathrm{F}_{\text {-hitung }}$ melampaui nilai $\mathrm{F}_{\text {-tabel }}$ pada taraf uji $5 \%$.

Tabel 5. Analisis Ragam (ANOVA) Data Volume Potongan Tepi (Spur-knife waste) pada Rancangan Percobaan Faktorial 3 x 5

\begin{tabular}{|l|c|c|c|c|c|c|}
\hline \multirow{2}{*}{$\begin{array}{c}\text { Sumber } \\
\text { Keragaman }\end{array}$} & $\mathrm{db}$ & $\mathrm{JK}$ & $\mathrm{KT}$ & \multirow{2}{*}{$\mathrm{F}_{\text {hitung }}$} & \multicolumn{2}{|c|}{$\mathrm{F}_{\text {tabel }}$} \\
\cline { 6 - 7 } & & & & & $5 \%$ & $1 \%$ \\
\hline Ulangan & 3 & & & & & \\
\hline Perlakuan & 14 & 0.020 & 0.002 & -0.419 & 2.06 & 2.8 \\
\hline $\mathrm{A}=$ Mutu & 2 & 0.036 & 0.018 & 5.231 & 3.34 & 5.45 \\
\hline $\begin{array}{l}\text { B = Kelas } \\
\text { Diameter }\end{array}$ & 4 & 0.009 & 0.002 & 0.692 & 2.71 & 4.07 \\
\hline AB & 8 & 0.066 & 0.008 & -2.387 & 2.29 & 3.23 \\
\hline Galat & 28 & 0.097 & 0.004 & & & \\
\hline Total & 89 & 0.077 & & & & \\
\hline
\end{tabular}

Keterangan:

ns $=$ tidak berbeda nyata pada $\alpha=0,05$

${ }^{* *}=$ berbeda sangat nyata pada $\alpha=0,01$

Sebenarnya volume potongan tepi tidak berhubungan langsung dengan mutu blok asalnya, karena lebar potongan tepi peda kedua sisi pisau kerat mesin rotary lebih dipengaruhi oleh ukuran blok asalnya. Jika ukuran panjang blok mendekati ukuran panjang finir yang dikehendaki, maka finir potongan tepi akan kecil. sebaliknya jika pemotongan blok diberikan kelebihan 
(allowance) yang besar maka dengan sendirinya akan memberikan sisa finir potongan tepi yang lebar, artinya volume finir potongan tepi akan meningkat atau tinggi.

Tabel 5 mengisyaratkan bahwa dari analysis of variance (ANOVA) terhadap sumber-sumber varians pada percobaan ini, ternyata semua bentuk perlakuan tidak memberikan pengaruh signikan terhadap volume potongan tepi. Agaknya besar kecilnya volume potongan tepi ini lebih banyak dipengaruhi oleh allowance, kelebihan pada ukuran panjang log-block yang terkadang terlalu besar jauh melebihi panjang finir yang dikehendaki.

\section{KESIMPULAN}

Rata-rata hasil kupas sawn-log (logblock) di mesin rotary lathe spindleless dalam bentuk finir gulung (continuous veneer) $55 \%-57 \%$; $18 \%-25 \%$ dalam bentuk finir untuk inti (poly piece core) Volume empulur (log-core) 11\%-15\%. Sementara finir potongngan tepi oleh pisau kerat spurknife rata-rata mendekati $1 \%$. Berdasarkan uji statistik dengan rancangan percobaan faktorial, ternyata hanya faktor mutu blok yang mampu memberikan pengaruh signifikan terhadap rendemen finir atau bahan lainnya yang dihasilkan dalam proses pengupasan blok menjadi finir, walaupun sayangnya belum sigifikan terhadap hasil finir gulung (baru mendekati signifikan pada $\alpha=0,05$. Interaksi kedua perlakuan yang diuji juga tidak menunjukkan pengaruh signifikan terhadap rendemen finir dan hasil kupas lainnya.

\section{UCAPAN TERIMAKASIH}

Penghargaan dan ucapan terimakasih terutama di tujukan kepada bapak Ardiansyah dan Bapak Muchtarom yang membimbing langsung selama penelitian ini di pabrik, dan secara umum kepada seluruh Pimpinan PT Rimba Raya Lestari di Kabupaten Kutai Kertanegara yang telah memfasilitasi pelaksanaan penelitian ini sehingga dapat terlaksana dengan baik.

\section{DAFTAR PUSTAKA}

Alfian, L. dan Sari, N.M. 2019. Rendemen Finir pada Mesin Rotary Berdasarkan Kelompok Jenis Kayu pada Industri Kayulapis di PT Surya Satrya Timur. Jurnal Sylva Scienteae Vol. 02 No. 4. ISSN 2622-8963 (media online).

Baldwin, R.F. $1981 . \quad$ Plywood Manufacturing Practices. Revised, Second Edition. Miller Freeman Publication, Inc. San fransisco.

Balfas, J. dan Malik, J., 2020. Pengaruh Umur Pohon, Posisi Batang, Tebal Venir dan Komposisi Panel Inti Sawit Terhadap Produksi Kayulapis Mindi. Jurnal Penelitian Hasil Hutan Vol. 38 No. 3; 189-198.

Britannica. 2002. Encyclopedia Britannica 2002. Deluxe Edition. Dalam Bentuk CD Room.

Dumanauw, J.F. 1996. Mengenal Kayu. Pendidikan Industri Kayu Atas (PIKA) Penerbit Kanisius. Semarang.

Frûehwald, A. 1986. Plywood, A Short Introduction into Its Production, Quality Control and Properties. Visiting Proffessor to the Faculty of Forestry, Mulawarman University. Samarinda. (Not publicated).

Gaspersz, V. 1994. Metode Perancangan Percobaan untuk IImu-ilmu Pertanian, Ilmu-ilmu Teknik dan Biologi. Armico. Bandung

Gomez, Kwanchai A dan Gomez, Artro A. 1995. Prosedur Statistik untuk Penelitian Pertanian. Edisi Kedua. Penerbit Universitas Indonesia (UIPress). Jakarta. Indonesia.

Haygeen, J.G dan Bowyer, J.L. 1993. Hasil Hutan dan IImu Kayu, Suatu Pengantar. Terjemahan Hadikusumo, Sutjipto A. Gajahmada University press. Yogyakarta.

Khoo, P.S., H'ng, P.S., Chin, K.L., Bakar, E.S., Mamiński, M., Raja-Ahmad, R-N., Lee, C.L., Ashikin, S.N., and Saharudin, M-H. 2018. 'Peeling of small diameter rubber log using spindleless lathe technology: evaluation of veneer properties from outer to inner radial section of log at different veneer thicknesses', European Journal of Wood and Wood Products, 76. 
Kollmann, F.F.P. dan Kuenzi, E.W. dan Stamp, A.J. (2013). Principles of Wood Science and Technology. Wood Based-Material. Springer-Verlag. New York. Heidelberg Berlin.

McGavin. 2016. Analysis of Small-Log Processing to Achieve Structural Veneer from Juvenile Hardwood Plantations. Doctor of Philosophy. Faculty of Science, School of Ecosystem and Forest Sciences the University of Melbourne.

Philips, D.R., Schoeder, J.G. dan Clark, A. 1980. Reduce Pine Veneer Losses by Selecting Blocks Properly. For. Ind.

Schulte, A dan Schone, D. 1996. Dipterocarp Forest Ecosystems, Towards Sustainable Management.
World Scientific. Singapore, New Jersey, London, Hongkong.

Steel, R.G.D. dan Torrie, J.H. 1993. Prinsip dan Prosedur Statistika, Suatu Pendekatan Biometrik. Edisi Kedua. Penerbit PT Gramedia. Jakarta.

Syafii, A. 2001. Analisis Volumetrik Konversi Kayu Bulat Menjadi Lembaran Finir pada Industri Kayulapis. Buletin Poltanesa. Volume I. No. 1. Politeknik Pertanian Negeri. Samarinda.

Syafii. 2019. Kayulapis, Teknik Pembuatan, Sifat-sifat dan Kegunaannya. Penerbit Garis Putih Pratama. Makassar.

Wood, A.D. and Linn, T.G. 1950. Plywood, Their Development, Manufacture and Application. Revised Edition. W. \& A.K. Johnston, Limited.Edinburgh and London. 